\title{
Combined Carcinoid and Adenocarcinoma
}

National Cancer Institute

\section{Source}

National Cancer Institute. Combined Carcinoid and Adenocarcinoma. NCI Thesaurus. Code C4139.

A malignant epithelial neoplasm composed of a mixture of neuroendocrine cells with morphologic and immunohistochemical characteristics of carcinoid tumor and malignant glandular cells. 